\title{
ASSESSMENT OF THE ANTIBIOTIC RESISTANCE OF BACTERIAL ISOLATES RECOVERED FROM DOG FEED SOLD IN ADO-EKITI METROPOLIS
}

ATERE Ayowole Victor

Address (es):

Department of Microbiology, Federal University of Technology, Akure, P.M.B 740 Akure, Nigeria.

*Corresponding author: victor_efosa001@yahoo.com

\section{ABSTRACT}

https://doi.org/10.36547/be.2020.3.4.81-83

Animal feed has been incriminated in many animal infectious diseases. This study was carried out to investigate and document the bacteriological safety of dog feed sold in Ado-Ekiti Metropolis. Five feed samples were analyzed, the bacterial load, coliform count, total Salmonella count as well as test for campylobacter was carried out on the feed samples. Pure culture of the isolates were subjected to antibiotic susceptibility test using disc diffusion method. The total bacterial count ranged between $4.41 \log _{10} \mathrm{CFU} / \mathrm{g}$ and $6.36 \log _{10} \mathrm{CFU} / \mathrm{g}$. All feed samples had coliform ranging between $2.09 \log _{10} \mathrm{CFU} / \mathrm{g}$ and $3.93 \log _{10} \mathrm{CFU} / \mathrm{g}$. Salmonella was only recovered from feed sample DED. Only sample DDL harbours Campylobacter sp. Other bacteria isolated from the feed were Escherichia coli, Bacillus sp, Enterobacter sp, Klebsiella sp, Staphylococcus sp and Lactobacillus sp. The antibiogram showed that nitofuratoin and ciproflocacin had the best activity where $93.10 \%$ (54 out of 58) were susceptible to the two antibiotic. Ampicilin was most resisted with only $36.21 \%$ (21) susceptibility. Thirty one (31) of the isolates showed resistance to 3 or more antibiotic constituting $53.44 \%$ of the entire bacterial isolate. Antibiotic resistance pattern mostly encountered were AMP, AMO, TLY and AMP, AMO, FUR with thirteen (13) isolates each. These results showed that dog feed may not be totally safe for the pets. Based on the type of bacteria isolated and the antibiotic resistance, good manufacturing practices should be ensured by manufactures in other to reduce the rate of contamination.

Keywords: Dogs, Campylobacter, Salmonella, Antibiotic, Resistance

\section{INTRODUCTION}

Animal feeds are so important to the overall productivity of the animal. In general, the composition of animal feed includes mixture of different ingredients that constitute the raw material. The ingredients may include cereals, fat supplements, vitamins, minerals, antioxidants as well as meat meal (Cabarkapa et al., 2009; Atere et al., 2015a).

When feed is contaminated, the quality of the feed is reduced, this contamination often emanates from the ingredients of both plant and animal origin. The quality and quantity of biological contamination is often dependent on the temperature and humidity of the feed and storage environment.

Researchers have showed that the major source of microbial infection in animal is often through the feed consumed, at times, these feeds are contaminated by additives (Atere, 2016). Several animal diseases and syndrome has been traced to the feed, such as diarrhoea, bacillary dysentery, salmonellosis, staphylococcosis, colibacillosis, erysipelas, listeriosis (Healing and Greenwood, 1991, Xin, 2013).

Generally, animal feed has been reported as a source of infection in poultry (Cabarkapa et al., 2009). The toxigenic content of the dog feeds are reported (Boermans and Leung, 2007). A potentially risky factor is the presence of microbial toxins of bacterial and fungal origin in the feed which could lead to food poisoning (Hussein and Brasel, 2001). However, little or no comprehensive information has been reported about the bacteriological contamination and antibiotic susceptibility of the bacteria isolated from dog feed. The bacteriology of the feed can give a clue to the risk feed may constitute, it can also create a public health issue since this can be a source of infection in humans. It is therefore imperative to investigate the bacteriological quality of dog feed sold around Ado-Ekiti metropolis.

\section{AIM AND OBJECTIVE}

This research was design to investigate the bacteriological quality of dog feeds by the way of determining the microbial load, the type of bacteria associated with each feed as well as the antibiotic susceptibility of the bacterial isolates.

\section{MATERIALS AND METHOD}

The materials used for this research was gotten from pet shops in Ado Ekiti. Triplicate samples of five different feed samples were collected and transported to the microbiology laboratory within two hours of collection.

\section{Determination of moisture content}

Five grams of the feed was weighed and dry to a constant weight in a dry oven (DHG-9101-1US Royalcare England). The change in weight divided by the initial weight multiply by 100 was recorded as the moisture content (AOAC, 2005).

\section{Determination of the Bacteriology of the feed}

The feed samples were aseptically weighed, 5 gram of each feed sample was homogenized in $45 \mathrm{ml}$ of sterile buffer peptone water. A serial dilution of the stock was then carried out using sterile buffered peptone water. The pour plate technique was used where $1 \mathrm{ml}$ of the diluted sample was plated on Nutrient agar, MacConkey and Salmonella-Shigella Agar. All plates were allowed to gel, and inverted then incubated at $37^{\circ} \mathrm{C}$ for $24 \mathrm{~h}$ in an incubator (DNP-9022A Royalcare England). The colonies on each of the plates were counted using colony counter. The colonies on the Nutrient agar was recorded as the total bacterial count, the coliforms were determined on MacConkey agar, the total salmonella was determined on Salmonella-Shigella Agar. Preston selective agar was used in testing for the presence of Campylobacter sp (Weese et al., 2005).

\section{Identification of bacteria isolates}

Pure culture of each isolates were made on nutrient agar. From the pure culture, the cultural characteristics of the colonies were determined. The gram reaction and biochemical testes were also carried out on each of the pure isolates according to the standard as described by Atere $\boldsymbol{e t}$ al. (2015b). The biochemical characteristics observed were citrate, methyl red voges-proskauer, nitrate, urease, oxidase, coagulase, and catalase.

\section{Antibiotic susceptibility}

Muller-Hinton agar was used for the antibiotic susceptibility. The organisms were standardized going by the McFarland standard. While the disk diffusion method was adopted, isolates were inoculated on the agar and the antibiotics disks were introduced. The plate was inverted and incubated in the incubator at a temperature of $37^{\circ} \mathrm{C}$ for $24 \mathrm{~h}$. The susceptibility and resistance of the bacteria isolates was determined based on the diameter of the zone of inhibition which was compare with the internationally acceptable standard.

\section{RESULTS}

The total bacterial count of the feed analyzed ranged between $4.28 \log _{10} \mathrm{CFU} / \mathrm{g}$ and $6.36 \log _{10} \mathrm{CFU} / \mathrm{g}$ in feed samples of PED and ERY respectively (Table 1). The highest coliform count was recorded in feed sample DDL with a value of $3.93 \log _{10} \mathrm{CFU} / \mathrm{g}$ which is significantly higher than all other samples. Salmonella $\mathrm{sp}$ was not isolated in four of the feeds, the salmonella count of $1.34 \log _{10} \mathrm{CFU} / \mathrm{g}$ was recorded for feed DED. The moisture content of the feed ranged from 9.16 $\%$ to $19.20 \%$. 
Table 1 The moisture content, total bacteria, coliform and Salmonella count of dog feed samples

\begin{tabular}{lcccc}
\hline Feed & $\begin{array}{c}\text { Total } \\
\text { bacterial } \\
\text { count } \\
\left(\log _{10} \mathbf{C F U} / \mathbf{g}\right)\end{array}$ & $\begin{array}{c}\text { Total } \\
\text { coliform } \\
\text { count } \\
\left(\log _{\mathbf{1 0}} \mathbf{C F U} / \mathbf{g}\right)\end{array}$ & $\begin{array}{c}\text { Total } \\
\text { salmonella } \\
\left(\log _{\mathbf{1 0}} \mathbf{C F U} / \mathbf{g}\right)\end{array}$ & $\begin{array}{c}\text { Moisture } \\
\text { content } \\
(\%)\end{array}$ \\
\hline DDL & $5.68 \pm 0.35^{\mathrm{c}}$ & $3.93 \pm 0.20^{\mathrm{d}}$ & 0 & $19.2 \pm 2.50^{\mathrm{c}}$ \\
DCO & $4.77 \pm 0.40^{\mathrm{ab}}$ & $3.09 \pm 0.40^{\mathrm{c}}$ & 0 & $9.16 \pm 0.83^{\mathrm{a}}$ \\
$\mathrm{ERY}$ & $6.36 \pm 0.50^{\mathrm{d}}$ & $2.09 \pm 0.30^{\mathrm{a}}$ & 0 & $17.50 \pm 2.50^{\mathrm{bc}}$ \\
PED & $4.28 \pm 0.10^{\mathrm{a}}$ & $2.33 \pm 0.15^{\mathrm{ab}}$ & 0 & $11.87 \pm 1.49^{\mathrm{ab}}$ \\
DED & $4.41 \pm 0.16^{\mathrm{ab}}$ & $3.15 \pm 0.10^{\mathrm{a}}$ & $1.34 \pm 0.02$ & $10.00 \pm 1.70^{\mathrm{a}}$ \\
\hline
\end{tabular}

Table 2 showed the distribution of the isolated bacteria in the feed samples. A total of fifty eight (58) bacterial isolates were recovered from all the feeds samples with 8 different bacteria species. Bacillus sp was recovered from DDL, DCO, and ERY while E. coli was present in all the feed sample analyzed. Staphylococcus sp was found in ERY, PED and DED. Only DCO had Enterobacter sp. Campylobacter sp, was found only in DDL.
Table 2 Number of Bacterial isolates recovered from dog feed samples

Feeds

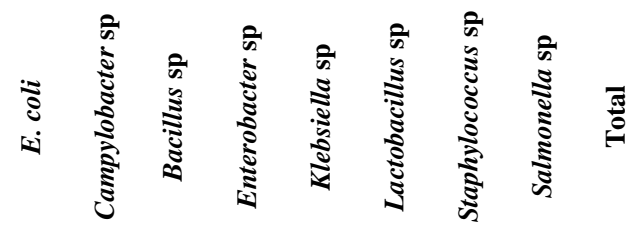

\begin{tabular}{lccccccccc} 
DDL & 6 & 3 & 4 & - & - & - & - & - & 13 \\
DCO & 4 & - & 4 & 2 & 2 & - & - & - & 12 \\
ERY & 3 & - & 2 & - & - & 6 & 3 & - & 14 \\
PED & 2 & - & - & - & 1 & - & 2 & - & 5 \\
DED & 5 & - & - & - & - & - & 3 & 6 & 14 \\
Total & 20 & 3 & 10 & 2 & 2 & 6 & 8 & 6 & 58 \\
\hline
\end{tabular}

Table 3 showed the susceptibility of the bacteria isolate to the antibiotic used in this research. The bacterial isolates are most susceptible to nitrofurantoin and ciprofloxacin with 54 of the bacterial isolates being susceptible constituting $93.10 \%$ of the total isolates. The least active antibiotic was ampicillin with only $36.21 \%(21)$ susceptible.

$\underline{\text { Table } 3 \text { Antibiotic susceptibility profile of bacterial isolates recovered from dog feed samples }}$

\begin{tabular}{|c|c|c|c|c|c|c|c|c|c|c|c|c|}
\hline & & CEF & CEZ & AMO & OFL & TLY & CIP & ENR & NIT & FUR & GEN & AMP \\
\hline & Bacillus sp $\mathrm{n}=4$ & 4 & 3 & 3 & 4 & 1 & 4 & 2 & 4 & 1 & 3 & 1 \\
\hline \multirow[t]{3}{*}{ DDL } & Campylobacter $\mathrm{sp} \mathrm{n}=3$ & 2 & 2 & 1 & 2 & 2 & 2 & 1 & 2 & 1 & 3 & 2 \\
\hline & E. coli $\mathrm{n}=6$ & 4 & 5 & 1 & 5 & 5 & 5 & 4 & 6 & 4 & 6 & 2 \\
\hline & Enterobacter $\mathrm{sp} \mathrm{n}=2$ & 2 & 2 & 2 & 2 & 1 & 2 & 2 & 2 & 2 & 2 & 1 \\
\hline \multirow{4}{*}{ DCO } & E. coli $\mathrm{n}=4$ & 3 & 4 & 2 & 4 & 2 & 4 & 2 & 4 & 1 & 3 & 1 \\
\hline & Bacillus sp $\mathrm{n}=4$ & 4 & 4 & 3 & 4 & 2 & 4 & 4 & 4 & 3 & 4 & 3 \\
\hline & Klebsiella $\mathrm{sp} \mathrm{n}=2$ & 2 & 2 & 2 & 2 & 1 & 2 & 2 & 2 & 2 & 2 & 1 \\
\hline & E. coli $\mathrm{n}=3$ & 2 & 1 & 1 & 2 & 1 & 3 & 1 & 2 & 1 & 2 & 0 \\
\hline \multirow{4}{*}{ ERY } & Lactobacillus sp $\mathrm{n}=6$ & 6 & 6 & 5 & 6 & 5 & 6 & 5 & 6 & 4 & 6 & 3 \\
\hline & Bacillus sp $\mathrm{n}=2$ & 2 & 1 & 0 & 2 & 2 & 2 & 1 & 2 & 2 & 2 & 1 \\
\hline & Staphylococcus $\mathrm{sp} \mathrm{n}=3$ & 1 & 3 & 3 & 3 & 1 & 3 & 3 & 3 & 3 & 3 & 2 \\
\hline & Klebsiella $\mathrm{sp} \mathrm{n}=1$ & 1 & 1 & 0 & 0 & 0 & 1 & 1 & 1 & 0 & 1 & 0 \\
\hline \multirow[t]{3}{*}{ PED } & Staphylococcus $\mathrm{sp} \mathrm{n}=2$ & 2 & 2 & 0 & 2 & 0 & 2 & 2 & 2 & 0 & 0 & 0 \\
\hline & E. coli $\mathrm{n}=2$ & 2 & 2 & 2 & 2 & 2 & 2 & 2 & 2 & 0 & 2 & 0 \\
\hline & Salmonella $\mathrm{sp} \mathrm{n}=6$ & 5 & 4 & 3 & 5 & 4 & 6 & 2 & 5 & 3 & 5 & 2 \\
\hline \multirow[t]{2}{*}{ DED } & E. coli $\mathrm{n}=5$ & 4 & 4 & 2 & 5 & 3 & 4 & 3 & 4 & 2 & 4 & 1 \\
\hline & Staphylococcus $\mathrm{sp} \mathrm{n}=3$ & 2 & 3 & 1 & 3 & 1 & 2 & 1 & 3 & 3 & 2 & 1 \\
\hline Total & 58 & 48 & 49 & 31 & 53 & 33 & 54 & 38 & 54 & 32 & 50 & 21 \\
\hline
\end{tabular}

Furasol (FUR), Gentamicin (GEN), Ampicillin (AMP).

The antibiotic resistance pattern AMP, AMO, TLY and AMP, AMO, FUR were the most encountered resistance pattern with 13 bacterial isolates each displaying such resistance pattern. NIT, GEN, AMP and CIP AMP TLY resistance patterns were least encountered with one isolate each displaying this antibiotic resistance pattern (table 4). Table 5 showed the distribution of bacterial isolates showing resistance to 3 or more antibiotics. A total of 31 out of 58 bacterial isolates recovered from dog feeds showed resistance to 3 or more antibiotics.

Table 4 Antibiotic resistance pattern of Bacterial isolates recovered from dog feed samples

\begin{tabular}{|c|c|c|c|c|c|c|c|c|c|c|c|c|c|c|c|c|c|c|}
\hline \multirow[b]{2}{*}{ Resistance pattern } & \multicolumn{3}{|c|}{ DDL } & \multicolumn{4}{|c|}{ DCO } & \multicolumn{4}{|c|}{ ERY } & \multicolumn{3}{|c|}{ PED } & \multicolumn{3}{|c|}{ DED } & \multirow[b]{2}{*}{ 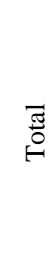 } \\
\hline & 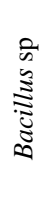 & 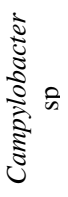 & 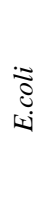 & 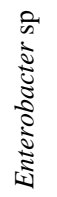 & $\begin{array}{l}\ddot{\tilde{\delta}} \\
\dot{0} \\
\dot{1}\end{array}$ & 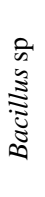 & 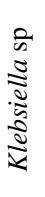 & $\begin{array}{l}\ddot{\tilde{\delta}} \\
\dot{0} \\
\dot{1}\end{array}$ & 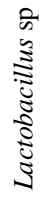 & 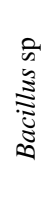 & 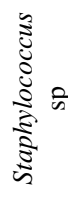 & 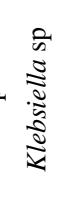 & 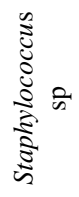 & $\begin{array}{l}: \overrightarrow{0} \\
0 \\
\dot{0}\end{array}$ & 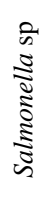 & $\begin{array}{l}\ddot{\delta} \\
\dot{0}\end{array}$ & 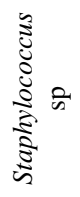 & \\
\hline AMP, AMO, TLY & 1 & 1 & 1 & 0 & 1 & 1 & 0 & 1 & 0 & 0 & 0 & 1 & 2 & 0 & 2 & 1 & 1 & 13 \\
\hline AMP, AMO, FUR & 1 & 1 & 0 & 0 & 1 & 1 & 0 & 1 & 1 & 0 & 0 & 1 & 2 & 0 & 2 & 2 & 0 & 13 \\
\hline CEF, CEZ, OFL & 0 & 0 & 1 & 0 & 0 & 0 & 0 & 1 & 0 & 0 & 0 & 0 & 0 & 0 & 0 & 1 & 0 & 3 \\
\hline NIT, GEN, AMP & 0 & 0 & 0 & 0 & 0 & 0 & 0 & 0 & 0 & 0 & 0 & 0 & 0 & 0 & 1 & 0 & 0 & 1 \\
\hline ENR, AMP, AMO, FUR & 0 & 1 & 0 & 0 & 0 & 0 & 0 & 0 & 0 & 0 & 0 & 0 & 0 & 0 & 2 & 0 & 0 & 3 \\
\hline CIP, AMP, TLY & 0 & 0 & 0 & 0 & 0 & 0 & 0 & 0 & 0 & 0 & 0 & 0 & 0 & 0 & 0 & 1 & 0 & 1 \\
\hline
\end{tabular}

Key: Ceftazidime (CEZ) and Cefuroxime (CEF) Amoxicillin(AMO), Ofloxacin (OFL), Tylosin (TLY), Ciprofloxacin (CIP), Enrofloxacin (ENR), Nitrofurantoin (NIT), Furasol (FUR), Gentamicin (GEN), Ampicillin (AMP). 
Table 5 Bacterial isolates recovered from dog feeds showing resistance to 3 or more antibiotics

\begin{tabular}{|c|c|c|c|c|c|c|c|c|c|}
\hline Feed & $\begin{array}{c}\tilde{8} \\
\dot{8}\end{array}$ & 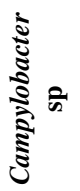 & 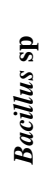 & 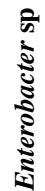 & 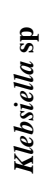 & 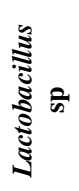 & 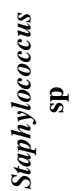 & 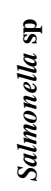 & हैّ \\
\hline DDL & 3 & 2 & 3 & - & - & - & - & - & 8 \\
\hline DCO & 3 & - & $\mathbf{0}$ & 0 & 0 & - & - & - & 3 \\
\hline ERY & 3 & - & 1 & - & - & 1 & 1 & - & 6 \\
\hline PED & 0 & - & - & - & 1 & - & 2 & - & 3 \\
\hline DED & 4 & - & - & - & - & - & 3 & 4 & 11 \\
\hline Total & 13 & 2 & 4 & 0 & 1 & 1 & 6 & 4 & 31 \\
\hline
\end{tabular}

\section{DISCUSSION}

Foods have been recognized as the major health determinant, what you eat determined your wellbeing. Animal feed has been reported as a source of microbes in farmed animals and poultry (Weese et al., 2005; Atere et al., 2015a). This may also be true of pets. The bacterial load and the type of bacteria present in the feed samples analyzed indicated that the feeds might not be totally safe for the animals. Isolating Campylobacter sp in one of the feed sample is an indication that such a food is so unfit. The bacteria recovered is an indication of potential hazard to the animals. This study revealed that eight (8) bacterial species were isolated from these feeds. The occurrence of these bacteria in the feed and direct consumption of bacterial contaminated feed or their toxins by such animal may constitute a public health issue (Fraizer and Westhoff, 1978). Animal feeds are rich in nutrients, this encourages the proliferation of microorganism and when the environmental/storage conditions such as moisture increased, the growth of these bacteria are pronounced (Atere et al., 2015).

In a similar investigation carried out by Weese et al. (2005), E. coli, Salmonella sp Staphylococcus sp and Clostridium sp were isolated. Meanwhile there was no Clostridium sp isolated in this research, a report of coliform present in all the samples analyzed is also similar to what is observed in this research where E.coli was isolated in all the feed samples (Weese et al., 2005). Nemser et al. (2014) reported that Salmonella, Listeria and E. coli are often isolated in pet food, the bacteria load and the type of bacteria isolated from feed can tell more about the safety of the feed.

In a previous research of Atere et al. (2015a), it was reported that the presence of coliforms in poultry feed may have resulted from feacal or environmental contamination. This might also be true of what is observed in this study where the coliform level of three of the feeds are higher than what is recommended by Canadian food inspection agency where the maximum level of coliform should be less or equal to $1000 \mathrm{CFU} / \mathrm{g}$ (Fraizer and Westhoff, 1978). Coliform count is always seen as index of sanitation. The increase above this level in this feed may suggest that good manufacturing practices are not being stocked to, or may have resulted from improper handling.

Isolating Salmonella sp in one of the feed is of concern. This is because salmonella is a pathogen of many farm animals including pets like dog and cats. There are indications that there could be zoonosis through direct contact or through environmental contamination within the house hold (Atere et al., 2015b). The presence of Campylobacter sp in one of five feeds is of concern, this is because it has been responsible for food infection in humans (Brieseman, 1990). Meanwhile Campylobacter sp is one of the recognized enteropathogen of dogs and cats, where contact with these pets has been reported as the means of transmission of Campylobacter sp to human population (Brieseman, 1990).

The presence of Staphylococcus sp in three of the feed samples may have resulted from human source, possibly during dispensing, since these are normal flora of human body. It should be recalled that Staphylococcus aureus and Salmonella sp are capable of producing acute and chronic infection in all or most type of animal (Mallinson, 1984). Therefore, the effect these bacteria could have on dogs should not be underestimated.

The antibiotic susceptibility of the bacterial isolate can also be of great public health concern. Though the isolates are well susceptible to the antibiotic used in this research when compared with the susceptibility of bacteria isolates from poultry feed (Atere et al., 2015a). In research of Atere et al. (2018), it was reported that the bacterial isolates from dog are less resistant to antibiotic when compare to isolates recovered from poultry. The reason for the increased susceptibility of bacterial isolates recovered from the dog feed when compared with that of poultry may be related to what Atere et al. (2018) earlier reported as the sub-therapeutic addition of antibiotic to poultry feeds. Nevertheless, this study showed that some of the bacteria showed multiple resistance, it is of great importance to acknowledge that some of the bacteria multiple resistance strain can find human population, through a trend of being infectious in the pets that feeds on them and through human contact with the pets finds its way into human population.

\section{CONCLUSION}

There are potential risks attached to the pet feeds, the type of bacteria found in the feed, the load of the bacteria and the antibiotic resistance of these organisms are of public health concern. The storage condition and the moisture content can also encourage the growth of bacteria. Chemical amendment, heat treatment, careful sourcing for raw materials and good manufacturing practices can go a very long way in reducing bacterial infestation of the feed thereby, improving the safety of the feed.

\section{REFERENCES}

AOAC (2005). Official methods of Analysis international. $18^{\text {th }}$ edition. Association of official Analytical chemists. USA.

Atere, V. A, Bamikole, A. M. and Ajurojo, O. A. (2015a). Antibiotic Susceptibility of Bacteria Isolated from Poultry Feeds Sold in Ado Ekiti, Nigeria. Journal of Advancement in Medical and Life Sciences V3I2. https://doi:10.15297/JALS.V3I2.06.

Atere, V. A., Bamikole, A. M., Ajurojo, O. A. and Alo, O. S. (2015b). Antimicrobial Resistance Pattern of Pathogenic Escherichia coli Isolated from Chicken Liver and Trachea. Journal of Advancement in Medical and Life Sciences. V3I3. https://doi:10.15297/JALS.V3I3.02

Atere A. V. (2016). Multidrug resistant Salmonella sp isolated from chicken. International Journal of biological research 4(1): 64-66. https://doi:10.14419/ijbr.v4il.6030

Atere, A.V., Alo, O. S. and Daniel, F. (2018). Comparative study of antibiotic resistance in bacteria isolated from dog and chicken. International Journal of scientific world 6 (1): 34-37. https://doi10.14419/ijsw.v6il.8744

Boermans, J. H. and Leung, M. K. C. (2007). Mycotoxins and the pet food industry: Toxicological evidences and risk assessment. International Journal of food Microbiology, 119: 95-102. https://doi:10.1016/j.ijfoodmicro.2007.07.063

Brieseman, M. A. (1990). A further study of the Epidemiology of Campylobacter jejuni infection. N Z Med J. 103: 207-209.

Cabarkapa, I., Kokic, B., Plavsic, D., Ivanov, D. and Levic, J. (2009). Microbiological safety of animal feed. Biotechnology in Animal Husbandry, 25: $1155-1162$.

Fraizer, W. C and Westhoff, D. C. (1978). Food Microbiology. $3^{\text {rd }}$ Edition Tata McGraw Hill Publishing Company Limited, New Delhi.

Healing, T. O and Greenwood, M. H. (1991). Frequency of Isolation of Campylobacter spp, Yersinia spp and Salmonella spp from small mammals. Southern Britain International Journal of Environmental Health Research. 1: 54 -62 .

Hussein, S. H. and Brasel, M. J. (2001). Toxicity, metabolism and impact of mycotoxins on humans and animals. Toxicology, 167:101-134. https://doi:10.1016/s0300483x(01)00471-1

Mallinson E. T. (1984). Infectious diseases. In Animal Health. Jack Hayes (ed) Bureau of animal Industry (publisher), Maryland USA.

Nemser, S, M., Doran, T., Grabenstein, M., McConnell, T., McGrath, T., Pamboukia, R., Smith, A. C., Achen, M., Danzeizen, G., Kim, S., Liu, Y., Robeson, S., Rosario, S., Wilson, M. K. and Reimschuessel, R. (2014). Investigation of Listeria, Salmonella and Toxigenic Escherichia coli in various pet foods. Foodborne pathogen and disease 11(9): 706-709. http://doi:10.1089/fpd.2014.1748

Weese, J. S., Rousseau, J. and Arroyo, L. (2005). Bacteriological evaluation of commercial canine and feline raw diets. Canadian Veterinary Journal 46: 513516.

Xin, L. (2013).Pet Food Safety. U S Food and Drug Administration Protecting and Promoting Public Health. FASS 2013 Symposium Washington DC. www.fda.gov/FASS2013Symposium 